Riskey, D. R., Parducci, A., \& Beauchamp, G. K. (1979). Effects of context in judgments of sweetness and pleasantness. Perception \& Psychophysics, 26, 171-176.

SAS Institute (1985). SAS user's guide: Statistics, Version 5 edition. Cary, NC: Author.

SCHIFFERSTEIN, H. N. J. (1994). Sweetness suppression in fructose/ citric acid mixtures: A study of contextual effects. Perception \& Psychophysics, 56, 227-237.

Schifferstein, H. N. J., \& Frijters, J. E. R. (1992a). Contextual and sequential effects on judgments of sweetness intensity. Perception \& Psychophysics, 52, 243-255.

Schifferstein, H. N. J., \& Frijters, J. E. R. (1992b). Sweetness does not habituate during a sip-and-spit experiment. Physiology \& Behavior, 51, 331-337.

SCHIFFERSTEIN, H. N. J., \& KuIPER, W. E. (1995). (Pseudo)sequence effects in hedonic judgments. Manuscript submitted for publication.

Schiffman, S. S., \& Erickson, R. P. (1971). A theoretical review: A psychophysical model for gustatory quality. Physiology \& Behavior, 7, 617-633.

Settle, R. G., Meehan, K., Williams, G. R., Doty, R. L., \& Sisley, A. C. (1986). Chemosensory properties of sour tastants. Physiology \& Behavior, 36, 619-623.

Sherif, M., \& Hovland, C. I. (1961). Social judgment: Assimilation and contrast effects in communication and attitude change. New Haven, CT: Yale University Press.

Stillman, J. A. (1993). Context effects in judging taste intensity: A comparison of variable line and category rating methods. Perception \& Psychophysics, 54, 477-484.

WAGNer, M., \& BAIRD, J. C. (1981). A quantitative analysis of sequential effects with numeric stimuli. Perception \& Psychophysics, 29, 359-364

WARD, L. M. (1979). Stimulus information and sequential dependencies in magnitude estimation and cross-modality matching. Journal of Experimental Psychology: Human Perception \& Performance, 5, 444-459.

WARD, L. M. (1982). Mixed-modality psychophysical scaling: Sequential dependencies and other properties. Perception \& Psychophysics, 31, 53-62.

WARD, L. M. (1985). Mixed-modality psychophysical scaling: Interand intramodality sequential dependencies as a function of lag. Perception \& Psychophysics, 38, 512-522.

WARD, L. M., \& LockHEAD, G. R. (1970). Sequential effects and memory in category judgments. Journal of Experimental Psychology, 84, 27-34.

WARD, L. M., \& LOCKHEAD, G. R. (1971). Response system processes in absolute judgment. Perception \& Psychophysics, 9, 73-78.

WiLliams, R. B. G. (1988). Intermediate statistics for geographers and earth scientists. London: Macmillan.

(Manuscript received April 10, 1995;

revision accepted for publication October 19, 1995.)

\title{
Nominations for the Editorship of Memory \& Cognition
}

Nominations are solicited for the editorship of Memory \& Cognition. The term of the present editor, Geoffrey R. Loftus, expires at the end of 1997. The new editor will begin an official 4-year term on January 1, 1998, and will begin to receive manuscripts early in January 1997. The Publications Committee of the Psychonomic Society expects to appoint the new editor by November, 1996.

Nominations (including self-nominations) should be submitted by August 1, 1996, to:

Keith Rayner

Chair, Memory \& Cognition Search Committee

Psychology, Tobin Hall

University of Massachusetts

Amherst, MA 01003

e-mail: rayner@psych.umass.edu 